\title{
Impact of the Exchange Rate and Price Volatility on FDI Inflows: Case of Morocco and Turkey
}

\author{
Azzouzi Asmae ${ }^{1} \&$ Bousselhami Ahmed ${ }^{2}$ \\ ${ }^{1} \mathrm{Ph} . \mathrm{D}$ student at the Faculty of Law, Economics and Social Sciences of Tangier, Research Group on Economics, Finance \\ and Development (EFED), Abdelmalek Essaâdi University, Morocco \\ ${ }^{2}$ Professor of Economics at the Faculty of Law, Economics and Social Sciences of Tangier, Research Group on Economics, \\ Finance and Development (EFED), Abdelmalek Essaâdi University, Morocco \\ Correspondence: Azzouzi Asmae, Ph.D student at the Faculty of Law, Economics and Social Sciences of Tangier, \\ Research Group on Economics, Finance and Development (EFED), Abdelmalek Essaâdi University, Morocco.
}

Received: March 1, 2019

doi:10.11114/aef.v6i3.4218
Accepted: April 8, $2019 \quad$ Available online: April 21, 2019

URL: https://doi.org/10.11114/aef.v6i3.4218

\begin{abstract}
This paper aims to examine empirically the impact of price and real exchange rate volatility on Foreign Direct Investment (FDI) inflows. The sample used is based on the Mediterranean countries of Morocco and Turkey for the period 19902017. Empirical findings for Morocco revealing that in both short and long-terms, real exchange rate volatility is negative and highly significant. Price volatility depicts a positive effect, which means that greater volatility of inflation may cause greater marginal profitability of capital and hence increase investment. On the other hand, for Turkey, FDI inflows are found more elastic to domestic price fluctuations. The exchange rate volatility, instead, turned out to have a positive but insignificant effect. In addition, we found that the potential market size rate, institution quality, and infrastructure appear to be the key factors in attracting foreign capital in both countries. As for trade openness, a positive effect on FDI flows is only perceptible in Morocco. In addition, the series of structural reforms carried out by Turkish government have generated real benefits for foreign investors by creating the adequate environment. This has allowed Turkey to overcome the problems it was facing in attracting foreign investment during the period analysed.
\end{abstract}

Keywords: FDI inflows, GARCH-M, inflation volatility, exchange rate volatility, ARDL

JEL Classification: C32; F21; F23

\section{Introduction}

International Direct Investment (IDI) ${ }^{1}$ is considered one of the major factors of financial stability that improves social well-being and enhances economic development (Gregorio, J., Borensztein, E., \& Lee, J.W. (1997), Lipsey (2001), Bird and Rajan (2002), Azmat and Basu (2007), Azman-Saini, Law and Ahmad. (2010), Svrtinov ,V.G., Trajkovska, G.O., \& Kostadinovki, A.(2013), Bibi. (2014) and Pundit, M. (2017))

The collection of statistical data on FDI is one of the essential elements for economic analysis and public policy formulation seeking to attract more FDI projects. The IMF's Balance of Payments Manual and the Organization for Economic Co-operation and Development (OECD) benchmark definition of Foreign Direct Investment provide practical guidance on how to collect statistical data on international direct investment in compliance with internationally agreed standards.

This definition reflects the objective of a resident entity in one economy (direct investor) obtaining a lasting interest in an enterprise resident in another economy (direct investment enterprise). The direct investor can be an individual an incorporated or unincorporated private or public enterprise, a government or a group of related incorporated or unincorporated enterprises which have a direct investment enterprise. There is a lasting interest implies the existence of a long-term relationship where the direct investor has ownership of a minimum of $10 \%$ share of the voting power or ordinary shares or the equivalent in the direct investment enterprise. Likewise, direct investment positions cover all

\footnotetext{
1 FDI are also known as international direct investment (IDI) by the OECD.
} 
financial claims and liabilities between direct investors and direct investment enterprises, with the exception of financial derivatives and specific exceptions for affiliated financial intermediaries.

The IMF published the $6^{\text {th }}$ edition of the Balance of Payments and International Investment Position Manual (BPM6) ${ }^{2}$, which was released in 2009 and follows the fifth edition released in 1993. This update is provided to highlight the international investment position (IIP) as an autonomous statistic in addition to the balance of payments (BOP). The IIP compiles the value of the stock of each financial asset and liability between residents and non-residents at a specific point as defined in the standard components of the Balance of Payments. The stock is the result of past external transactions plus adjustments such as exchange rate movements to account for the value of financial asset/liability as of date of reporting. The accounts in the IIP are direct investments, portfolio investments, financial derivatives and other investments.

In addition, BPM6 provides the standard framework for compiling of BOP and IIP statistics that depict the information for assessing a country's economic relations with the rest of the world to provide a fuller picture of major developments to be used for policy decisions.

The recording of the shares varies according to the percentage of a company's capital that the IMF recommends as the basic dividing line between direct investment and portfolio investment in the form of shareholdings. When the nonresident holds less than $10 \%$ of equity or equivalent voting rights in an enterprise, these should be recorded in the International Investment Position "IIP" as portfolio investment and not as direct investment. This changes when the direct investor acquires more than $10 \%$ shares in a direct investment. Only then, is the purchase of additional shares is recorded as direct investment in a balance of payments.

With national economies becoming more integrated and interconnected, foreign direct investments have come to be considered the primary motor of globalization. The liberalization of foreign trade in Turkey started after adoption of several structural reforms in 1980 following the balance of payments and debt crises of the late 1970s. In contrast, Morocco did not start attracting large inflows of FDI until the 1990s. Moroccan strategy to diversify its sources of investment by focusing more in the manufacturing sector aims to bring the sector's contribution to GDP from its current $14 \%$ to $23 \%$ by 2020 . Adopting a new approach under the framework of the Industrial Acceleration Plan 2014-2020 policy began targeting development and modernizing industry by establishing efficient 'eco-systems'.

"Global Foreign Direct Investment Country Attractiveness" (GFICA) Index ranks, represents the world inward FDI flows and stocks. The composite index describes a host country's attraction for FDI by considering all measurable and comparable aspects that can affect FDI decision. Indexes such as this one are used to give users, policy-makers and Investment Promotion Agencies (IPAs) a clear idea on how to improve the country's attraction for inward FDI. In their report of 2018, we found that Morocco is losing attractiveness by 1 rank, while Turkey remains stagnant from 2017 to 2018. Therefore, Turkey presents a high rank in FDI confidence Index by $50^{\text {th }}$ comparing to Morocco by 69th out of 109 countries.

One of the reasons given for increased FDI is the gradual recovering of the global economy after the financial crisis of 2007-2008 according to Lye-Koh, H.,Yean-The, S., \& Kiat-Tan,W. (2016). After this period, the world economy has returned to robust growth by following the theory of "engines of growth". The latter focused especially on FDI positive spillovers effects. FDI continue to be the fundamental source of foreign financing in the presence of an intense competition (see the report of OECD, 2002) . $^{3}$

This paper aims at highlighting how the macroeconomic uncertainty, as proxied by price and the real exchange rate volatility can enhance FDI inflows for both countries, Turkey and Morocco during the last three decades. The time span of the study has been selected because of the availability of data, which is drawn from the economic reforms due to major political changes that lead to increased FDI. Part of this was a response to the financial crisis but also to regime change that led to changes in monetary and fiscal policy.

The main motivation for this study is to provide an analysis that can show how foreign investors are encouraged to invest in any given country, the paper does this based on material drawn from Turkey and Morocco. Starting by Morocco, it ranked as the first attractive economy for investments flowing into the African continent, according to the latest Africa Investment Index of 2018 (All) by Quantum Global Research Lab. Morocco is in fact being recognized as one of the best emerging markets for overseas investment alongside Turkey which ranked as the second largest recipient of FDI in West Asia (behind Israel) according to the United Nations Conference on Trade And Development (UNCTAD) 2018 world

\footnotetext{
2 The BPM6 is consistent the System of National Accounts 2008 (2008 SNA), which set the statistical framework for national accounts, and with the 4th edition of the Benchmark definition of Foreign Direct Investment (BD4) of the OECD.

3 Report based on a study by the OECD secretariat in 2002, which was about Foreign Direct Investment for Development "MAXIMISING BENEFITS, MINIMISING COSTS".
} 
Investment report. In addition, the observation period was characterized by continuous financial crisis and high macroeconomic volatility. That was of great concern to us, and was the main reason to deal with this subject.

The present paper demonstrates the influence of price and exchange volatility on FDI by discussing the results obtained from both case studies. The rest of the paper as well as the methodology used will be discussed as follows. The second section gives a quick idea of the literature review on the topic, such as the relationship between the main variables. The third one presents the data and the methodology steps taken. Section 4 discusses the results obtained in light of the relevant literature. Finally, we conclude in section 5.

\section{Literature Review}

Several empirical studies have been conducted to analyze the effect of both exchange rate and price volatility on FDI. In this step, we will see two major categories of studies. The first category of studies focuses on the positive effect existent between the uncertainty variables and FDI. The second category tends to highlight the negative relationship. In the table, some of the studies examining the effect of exchange rate and price volatility on FDI are given.

Table 1. Relationship between price and exchange rate volatility and FDI survey

\begin{tabular}{|c|c|c|c|}
\hline Authors & Country & Method & Conclusion \\
\hline Andrew B.Abel (1983) & $\begin{array}{l}\text { A risk-neutral } \\
\text { competitive firm }\end{array}$ & $\begin{array}{l}\text { Stochastic model of } \\
\text { Pindyck }\end{array}$ & $\begin{array}{l}\text { Positive effect of price } \\
\text { uncertainty "on investment } \\
\text { decision" }\end{array}$ \\
\hline Itagaki (1981) & Multinational firm & Theoretical model & $\begin{array}{l}\text { Positive or negative effect of } \\
\text { Exchange rate uncertainty on } \\
\text { FDI }\end{array}$ \\
\hline Cushman (1988) & $\begin{array}{l}\text { United States from } \\
\text { the United } \\
\text { Kingdom, France, } \\
\text { Germany, Canada } \\
\text { and Japan }\end{array}$ & $\begin{array}{l}\text { Seemingly unrelated } \\
\text { regressions approach }\end{array}$ & $\begin{array}{l}\text { Significant positive } \\
\text { correlation between } \\
\text { exchange rate volatility and } \\
\text { FDI flows }\end{array}$ \\
\hline $\begin{array}{l}\text { Goldberg and Kolstad } \\
\text { (1995) }\end{array}$ & $\begin{array}{l}\text { Canada, Japon, and } \\
\text { UK }\end{array}$ & Regression analysis & $\begin{array}{l}\text { Positive effect of exchange } \\
\text { rate uncertainty on foreign } \\
\text { firms }\end{array}$ \\
\hline Benassy-Quere et al(2001) & $\begin{array}{l}42 \text { developing } \\
\text { Countries }\end{array}$ & Panel data analysis & $\begin{array}{l}\text { A negative impact of } \\
\text { exchange rate volatility on } \\
\text { flows of FDI }\end{array}$ \\
\hline Jason Kiat (2008) & South Africa & Linear regression analysis & $\begin{array}{l}\text { A negative effect of inflation } \\
\text { on FDI, while the effect of } \\
\text { exchange rate was debated. }\end{array}$ \\
\hline $\begin{array}{l}\text { Alba, JosephD, Park, } \\
\text { Donghyun And Wang, } \\
\text { Peiming (2010) }\end{array}$ & United States & $\begin{array}{l}\text { Two-state Markov } \\
\text { process }\end{array}$ & $\begin{array}{l}\text { A positive and significant } \\
\text { effect of the exchange rate } \\
\text { on FDI }\end{array}$ \\
\hline $\begin{array}{l}\text { H.Sharifi-Renani and } \\
\text { M.Mirfatah (2012) }\end{array}$ & Iran & $\begin{array}{l}\text { Johansen and Juselius's } \\
\text { cointegration approach }\end{array}$ & $\begin{array}{l}\text { Positive and significant } \\
\text { effect of exchange rate on } \\
\text { FDI }\end{array}$ \\
\hline Y.Samran (2013) & Pakistan & $\begin{array}{l}\text { OLS Ordinary Least } \\
\text { Square }\end{array}$ & $\begin{array}{l}\text { Positive and negative } \\
\text { impact, respectively, of } \\
\text { exchange rate and inflation } \\
\text { on FDI }\end{array}$ \\
\hline $\begin{array}{l}\text { E.Asmah and F. Kwaw } \\
\text { Andoh }\end{array}$ & Sub-Saharan & Linear panel model & $\begin{array}{l}\text { A robust negative and } \\
\text { significant impact of } \\
\text { exchange rate volatility on } \\
\text { FDI in African countries. }\end{array}$ \\
\hline
\end{tabular}


Table 1. Continued

\begin{tabular}{|c|c|c|c|}
\hline Authors & Country & Method & Conclusion \\
\hline $\begin{array}{l}\text { J.Sousa Martins, Luis } \\
\text { Laureano and R.Barradas } \\
(2015)\end{array}$ & Brazil & ARDL & $\begin{array}{l}\text { Negative impact of REER } \\
\text { Real effective exchange rate } \\
\text { volatility on FDI Inflows. }\end{array}$ \\
\hline Usman Ullah Khan & Pakistan & ARDL & $\begin{array}{l}\text { Negative impact of the } \\
\text { exchange rate on FDI }\end{array}$ \\
\hline $\begin{array}{l}\text { Dal Bianco and To Loan } \\
\text { (2017) }\end{array}$ & $\begin{array}{l}\text { Panel of } 10 \text { selected } \\
\text { Latin America }\end{array}$ & $\begin{array}{l}\text { Panel data analysis "fixed } \\
\text { effect" }\end{array}$ & $\begin{array}{l}\text { Significant negative impact of } \\
\text { exchange rate volatility on } \\
\text { FDI inflows }\end{array}$ \\
\hline
\end{tabular}

\section{Data and Methodology}

\subsection{Data}

This period was chosen because it is a source of a considerable amount of data as well as being a period of economic reform due to major political changes. The reforms were the result of the financial crisis and were characterized by changes in the exchange rate regime as well as changes in monetary and fiscal policy.

In order to better analyze our series, all variables are expressed as ratios of GDP (FDI, trade openness, financial development), growth rates (GDP, infrastructure) and variation rate (Real effective exchange rate and inflation volatility series).

Due to the data availability, the frequency of analysis is annual. Data collection from a variety of sources was used. Annual data on FDI (inward by \% of GDP), trade openness (measured as the sum of exports and imports as \% of GDP) and inflation (as annual average growth rate) are taken from CNUCED. GDP growth and the number of telephone mainlines per 100 inhabitant "infrastructure" were extracted from the World Bank database, while Real Effective Exchange Rate were obtained from the Bruegel REER database (Darvas, 2012). Regarding the institutional variables that represent a proxy for country-specific institutional quality such as political freedom (measured on 1 to 7 scale) are taken from the Freedom House index, which proxies governments' commitment to democratic values. Another institution variable used, in this study, is about Human Development Index "HDI" as a new approach for advancing human wellbeing is taken from Human Development Reports.

The integration of these institutional proxies is motivated by different recent studies, such as foreign direct investment (Büthe and Milner, 2008), international trade (Baier, Bergstrand, and Clance; Dür et al., 2014), foreign aid (Baccini and Urpelainen, 2012), human rights (Hafner-Burton, 2009), and democratization (Pevehouse, 2005 and Bürzel and Van Hüllen, 2015).

In light of the aforementioned studies, all focus was on how institutional features in a host country may stimulate FDI flows through several mechanisms. The main mechanism includes competition (democracy, human rights, and good governance clauses as means to invite trade and FDI especially). FDI inflow is quite high when a government can make a more credible commitment of its domestic policy choices.

Taking into account the findings of the reviewed literature, the influence of each determinant on FDI inflows can be expected to have the following signs:

Table 2. Expected signs of the coefficients

\begin{tabular}{ll}
\hline Independent Variable & Expected Sign \\
\hline VolEX & $(-)$ \\
Volprice & $(-)$ \\
GDP & + \\
OP & + \\
PR & + \\
INFRA & + \\
HDI & + \\
\hline
\end{tabular}




\subsection{Methodology}

To capture the volatility in the real exchange rate and in the inflation, a comprehensive empirical analysis of the conditional variance of these series have been carried out using autoregressive Conditional Heteroskedasticity model $(\mathrm{ARCH})$ and its generalization $(\mathrm{GARCH})$ models.

GARCH model is based on the assumption that the variance of the error terms of a variable is not equal over time. It is assumed that the variance is higher in some periods than others and that periods of larger variance are clustered together. ARCH/GARCH models treat heteroskedasticity present in the variables of interest as a variance to be modeled.

In this study, GARCH-M model of Engle et al. (1987), where "M" stands for GARCH in mean (Tsay, 2010). This model is considered as an extension of the basic GARCH framework which allows the conditional mean of a sequence to depend on its conditional variance or standard deviation. A simple GARCH-M $(1,1)$ model can be written as:

Mean equation:

$$
y_{t}=\mu+\lambda \sigma_{t}^{2}+\varepsilon_{t}, \quad \varepsilon_{t} \square N\left(0, \sigma_{t}^{2}\right)
$$

Variance equation:

$$
\sigma_{t}^{2}=\delta+\alpha_{1} \varepsilon_{t-1}^{2}+\beta_{1} \sigma_{t-1}^{2}
$$

Where, $\delta \succ 0, \alpha_{1} \succ 0$ and $\beta_{1} \succ 0$ and $\sigma_{\mathrm{t}}^{2}$ is the conditional variance. $\delta$ is the constant term, $\alpha_{1}$ is the parameter coefficient of the autoregressive lag, $\varepsilon_{\mathrm{t}-1}^{2}\left(\mathrm{ARCH}\right.$ term), $\beta_{1}$ is the parameter coefficient of the moving average lag, $\sigma_{\mathrm{t}-1}^{2}$

\section{(GARCH term).}

To construct the exchange rate volatility, we start by explaining the AR process from Box-Jenkins methodology in order to specify the optimal AR lags. The AR model is written as:

$$
\operatorname{REER}_{t}=\omega_{0}+\sum_{i=1}^{p} \omega_{i} \operatorname{REER}_{t-i}+\varepsilon_{i, t}
$$

To specify the AR lags, we used VAR model to define the number of lags through the information criteria.

Table 3. VAR model, number of lags defined through the information criteria

\begin{tabular}{ccccc|ccc|ccc|ccc|ccccc}
\hline & \multicolumn{10}{c|}{1} & \multicolumn{10}{c|}{ Lag / Criteria } \\
\cline { 2 - 14 } Country & AIC & SC & HQ & AIC & SC & HQ & AIC & SC & HQ & AIC & SC & HQ & AIC & SC & HQ \\
\hline MOROCCO & $4.46^{*}$ & $4.56^{*}$ & $4.48^{*}$ & 4.53 & 4.68 & 4.57 & 4.53 & 4.72 & 4.57 & 4.61 & 4.86 & 4.67 & 4.67 & 4.96 & 4.74 \\
TURKEY & $7.54^{*}$ & $7.63^{*}$ & $7.56^{*}$ & 7.56 & 7.71 & 7.60 & 7.64 & 7.84 & 7.69 & 7.60 & 7.85 & 7.66 & 7.68 & 7.98 & 7.76 \\
\hline
\end{tabular}

* Indicates lag order selected by the criterion

AIC: Akaike information criterion

SC: Schwarz information criterion

HQ: Hannan-Quinn information criterion

From the table above, the number of lags that AR specification must have, in order for the model to be feasible, is 1 AR (1) for both cases, where inflation and real Exchange Rate variables are expressed in logarithms.

The table reports GARCH-M $(1,1)$ estimation results. The presence of GARCH-M enables the generation of conditional variance series as the volatility proxy for the exchange rate and inflation rate of the sampled countries. 
Table 4. GARCH-M $(1,1)$ estimation result

\begin{tabular}{|c|c|c|c|c|c|c|}
\hline \multirow[b]{2}{*}{ Country } & \multicolumn{3}{|c|}{ Inflation } & \multicolumn{3}{|c|}{ Exchange rate } \\
\hline & $\operatorname{RESID}(-1)^{\wedge} 2$ & GARCH(-1) & $R^{2} / \operatorname{adj} R^{2}$ & $\operatorname{RESID}(-1)^{\wedge} 2$ & GARCH(-1) & $R^{2} / \operatorname{adj} R^{2}$ \\
\hline Morocco & $\begin{array}{l}(-) 0.41^{* *} \\
(0.00)\end{array}$ & $\begin{array}{l}0.67^{* *} \\
(0.00)\end{array}$ & $0.28 / 0.22$ & $\begin{array}{l}(-) 0.19^{*} \\
(0.02)\end{array}$ & $\begin{array}{l}0.86^{* *} \\
(0.00)\end{array}$ & $0.80 / 0.78$ \\
\hline Turkey & $\begin{array}{l}(-) 0.16^{*} \\
(0.01)\end{array}$ & $\begin{array}{l}1.26^{* *} \\
(0.00)\end{array}$ & $0.70 / 0.68$ & $\begin{array}{l}(-) 0.11^{*} \\
(0.01)\end{array}$ & $\begin{array}{l}0.94^{* *} \\
(0.00)\end{array}$ & $0.75 / 0.73$ \\
\hline
\end{tabular}

( ): P-values

*: $5 \%$ significance

**: $1 \%$ significance

However, GARCH model is strictly required that all of the coefficients have to be positive as we have seen before. In addition, the summation of ARCH terms (p) and GARCH terms (q) are closed to one. Evidently, both ARCH and GARCH parameters of these variables (Inflation, Real exchange rate) for both cases (countries) are significantly positive, which satisfied the specification requirement of non-negativity for all of the models. Moreover, the summation of ARCH terms and GARCH terms of each variable of each country are closed to one. Therefore, these variables can be used to construct at the same time price and exchange rate volatility for these countries.

The estimating model to investigate the impact of exchange rate and price volatilities on the FDI inward flows can be expressed by following the model of Dal Bianco and Nguyen (2017), which is inspired by the works of Lemi and Asefa (2001), Ajuwon (2013), Yousaf et al.(2013) and Mahmood et al. (2011). Their works lean on the augmented Solow (1956) growth model which incorporate technology, capital and labour strength, and human capital as an important factor of growth determinant in the economy. Following these studies, the model is specified as:

$$
F D I_{i t}=\alpha_{0}+\alpha_{1} \pi_{i t}+\alpha_{2} \operatorname{VolEX}_{i t}+\alpha_{3} I_{N S T I T}+\alpha_{4} G D P_{i t}+\alpha_{5} O_{i t}+\alpha_{6}{I N F R A_{i t}}_{i t} \alpha_{7} H D I_{i t}+\varepsilon_{i t}
$$

(i) indicates country at time $\mathrm{t}$ (year). $\pi$ and VolEX are price and real effective exchange rate volatility. INSTIT stands for political rights and it is measured on 1 to 7 scale to refer the degree of freedom status for each country. OP is trade openness, INFRA represents infrastructure quality by using a proxy for information structure about the number of telephone mainlines per 100 inhabitants. GDP is the GDP growth, HDI is Human Development Index which is a summary measure of average achievement in key dimensions of human development including life expectancy, education and income per capita indicators, $\alpha_{0}$ is the constant term of the regression. As is customary, $\varepsilon_{i t}$ represents an idiosyncratic error term.

\subsubsection{Descriptive Statistics}

Before starting the analysis, we have decided to present our variables using a descriptive table that takes into account each country's specificities of all the variables. The presentation of our variables is the starting point for the efficiency of our estimates.

As you can see in the following table, the result revealed that Turkey have had higher inflation and real exchange rate volatility in comparison with Morocco. Additionally, Morocco is looking quite open in terms of trade than Turkey. Moroccan institutional quality has hugely improved in the last 15 years in comparison with Turkey. In spite of this, Turkey has achieved a high degree of the political rights which refer to the exercise of freedom in the country (as a scale measurement: between 1.0 and 2.5 the status of a country is considered free and between 3.0 and 5.5 just partially free) compared to Morocco. Furthermore, it seems that Morocco is still lacking in infrastructure compared to Turkey. Regarding economic growth, we noticed an increase in the growth in the Turkish economy. As well as the average of foreign direct investment (in \% of GDP) over the period of our study is more important in Morocco than Turkey which means that Moroccan economy has been focusing heavily on building its trade relationship with foreigners and investment since these two components are considered generally as growth drivers for the country. 
Table 5. Descriptive statistics

\begin{tabular}{|c|c|c|c|c|c|c|c|}
\hline $\begin{array}{l}\text { Morocco } \\
\text { Variables }\end{array}$ & Obs & Min & Max & Mean & Std. Dev. & Skewness & Kurtosis \\
\hline FDI & 28 & 0.005 & 0.072 & 0.023 & 0.013 & 1.48 & 6.45 \\
\hline VolEX & 27 & $2.30 \mathrm{E}-05$ & 0.013 & 0.002 & 0.003 & 2.04 & 6.25 \\
\hline VolPRICE & 27 & -0.064 & 0.12 & 0.045 & 0.039 & -0.40 & 3.79 \\
\hline GDP & 28 & -0.054 & 0.123 & 0.038 & 0.037 & -0.17 & 3.63 \\
\hline INSTIT & 28 & 4 & 6 & 5 & 0.27 & 0.00 & 14.00 \\
\hline INFRA & 28 & 0.016 & 0.115 & 0.057 & 0.027 & 0.74 & 2.52 \\
\hline $\mathrm{OP}$ & 28 & 0.471 & 0.856 & 0.65 & 0.135 & 0.18 & 1.48 \\
\hline HDI & 28 & 0.45 & 0.66 & 0.56 & 0.06 & -0.01 & 1.66 \\
\hline $\begin{array}{l}\text { Turkey } \\
\text { Variables }\end{array}$ & Obs & Min & Max & Mean & Std. Dev. & Skewness & Kurtosis \\
\hline FDI & 28 & 0.0025 & 0.036 & 0.011 & 0.01 & 1.06 & 3.40 \\
\hline VolEX & 27 & 0.002 & 0.019 & 0.008 & 0.004 & 1.25 & 3.62 \\
\hline VolPRICE & 27 & 0.044 & 1.019 & 0.252 & 0.26 & 1.65 & 4.99 \\
\hline GDP & 28 & -0.059 & 0.111 & 0.047 & 0.05 & -1.07 & 3.12 \\
\hline INSTIT & 28 & 2 & 5 & 3.392 & 0.83 & 0.35 & 2.63 \\
\hline INFRA & 28 & 0.127 & 0.294 & 0.223 & 0.06 & -0.28 & 1.67 \\
\hline $\mathrm{OP}$ & 28 & 0.304 & 0.549 & 0.452 & 0.07 & -0.88 & 2.84 \\
\hline HDI & 28 & 0.579 & 0.791 & 0.682 & 0.07 & 0.09 & 1.75 \\
\hline
\end{tabular}

3.2.2 Correlation Matrix Test

This test is done in order to make a diagnosis on the basis of data to check any existence of strong correlation between the determinants of our regressions. The closer the value is to 1 or -1 , the stronger the linear correlation. The variables which have this strong relationship might be assumed as not explaining the model with other correlated variables. Which means that the two correlated variables cannot explain together the model, thus one of these two variables must be eliminated from the model.

Table 6. Correlation matrix

\begin{tabular}{|c|c|c|c|c|c|c|c|c|}
\hline \multirow[t]{2}{*}{ Morocco } & \multicolumn{8}{|c|}{ Correlation (Prob) } \\
\hline & GDP & HDI & INFRA & $\mathrm{OP}$ & INSTIT & Volprice & VolEX & FDI \\
\hline GDP & 1.00 & & & & & & & \\
\hline HDI & 0.08 & 1.00 & & & & & & \\
\hline INFRA & 0.05 & $0.69^{* * *}$ & 1.00 & & & & & \\
\hline OP & 0.02 & $0.94^{* * *}$ & $0.74^{* * *}$ & 1.00 & & & & \\
\hline INSTIT & -0.32 & -0.30 & -0.25 & -0.22 & 1.00 & & & \\
\hline Volprice & 0.03 & 0.23 & 0.28 & $0.36^{*}$ & -0.17 & 1.00 & & \\
\hline VolEX & -0.11 & $-0.74^{* * *}$ & $-0.56^{* * *}$ & $-0.63^{* * *}$ & $0.48^{* *}$ & 0.11 & 1.00 & \\
\hline FDI & 0.13 & $0.34^{*}$ & 0.13 & 0.32 & -0.17 & 0.05 & $-0.43^{* *}$ & 1.00 \\
\hline \multirow[t]{2}{*}{ Turkey } & \multicolumn{8}{|c|}{ Correlation (Prob) } \\
\hline & GDP & HDI & INFRA & $\mathrm{OP}$ & INSTIT & Volprice & VolEX & FDI \\
\hline GDP & 1.00 & & & & & & & \\
\hline HDI & 0.23 & 1.00 & & & & & & \\
\hline INFRA & -0.10 & $-0.35^{*}$ & 1.00 & & & & & \\
\hline $\mathrm{OP}$ & 0.27 & $0.68^{* * *}$ & 0.05 & 1.00 & & & & \\
\hline INSTIT & -0.15 & -0.14 & 0.08 & 0.16 & 1.00 & & & \\
\hline Volprice & 0.03 & -0.27 & $0.70^{* * *}$ & -0.03 & -0.04 & 1.00 & & \\
\hline $\begin{array}{l}\text { VOLEX } \\
\text { FDI }\end{array}$ & $\begin{array}{l}-0.29 \\
0.08\end{array}$ & $\begin{array}{l}-0.44^{* *} \\
0.59^{* * *}\end{array}$ & $\begin{array}{l}-0.54^{* * * *} \\
-0.01\end{array}$ & $\begin{array}{l}-0.69^{\text {**** }} \\
0.45^{* *}\end{array}$ & $\begin{array}{l}0.04 \\
-0.30\end{array}$ & $\begin{array}{l}-0.36^{*} \\
-0.25\end{array}$ & $\begin{array}{l}1.00 \\
-0.39^{* *}\end{array}$ & 1.00 \\
\hline
\end{tabular}

*: $10 \%$ significance

**: $5 \%$ significance

***: $1 \%$ significance

For the case of Turkey, there seems to be no strong linear relationship between any two variables. For Morocco, it is clear that there is a higher correlation between trade openness and the human development index by 0.94 (too close to 1). Therefore, we concluded there is a problem of strong correlation and we should eliminated one of them from the model by checking the one (trade openness or human development index) that is considered as having major impact on the model. 


\subsubsection{Multicollinearity Tests}

Through this component, we want to be sure from the previous result of high inter-correlations among the independent variables. That is why we tested the multicollinearity issues between variables of each Model by using Variance Inflation Factor (VIF) and tolerance measures to better explain the phenomenon. The VIF is based on the coefficient of determination R square to quantify the degree of multicollinearity between each independent variable and the model.

If the value is greater than 10 , it means that the variable under discussion has multicollinearity issues with the model, because it means that the variable is strongly correlated with another independent variable. In addition, the measure of tolerance indicates the percentage of variance that the dependent variable is explained by all other explanatory variables. Tolerance $=1 / \mathrm{VIF}$, then a small value under 0.1 indicates multicollinearity is problematic. In this case, those variables must be excluded from the model to have the best regression models.

Table 7. Multicollinearity statistics

\begin{tabular}{llllllllll}
\hline Country & Statistics & VOLPRICE & VOLEX & GDP & OP & INFRA & PR & DUM & HDI \\
\hline \multirow{2}{*}{ Morocco } & Tolerance & 0.54 & 0.11 & 0.21 & 0.07 & 0.36 & 0.24 & 0.72 & $6.22 * 10^{-4}$ \\
& VIF & 1.83 & 9.04 & 4.67 & 13.71 & 2.75 & 4.03 & 1.39 & 1606.51 \\
\cline { 2 - 8 } Turkey & Tolerance & 0.39 & 0.12 & 0.49 & 0.28 & 0.11 & 0.36 & 0.41 & $2.25 * 10^{-3}$ \\
& VIF & 2.51 & 7.78 & 2.01 & 3.47 & 8.80 & 2.73 & 2.39 & 444.13 \\
\hline
\end{tabular}

Table 8. Multicollinearity after adjustment

\begin{tabular}{lllllllll}
\hline Country & Statistics & VOLPRICE & VOLEX & GDP & OP & INFRA & PR & DUM \\
\hline \multirow{2}{*}{ Morocco } & Tolerance & 0.54 & 0.24 & 0.23 & 0.25 & 0.36 & 0.58 & 0.76 \\
& VIF & 1.83 & 4.06 & 4.27 & 3.95 & 2.77 & 1.71 & 1.31 \\
\cline { 2 - 8 } Turkey & Tolerance & 0.39 & 0.13 & 0.51 & 0.29 & 0.12 & 0.49 & 0.45 \\
& VIF & 2.51 & 7.67 & 1.96 & 3.45 & 8.26 & 2.02 & 2.22 \\
\hline
\end{tabular}

From the tables above, we found a surprising result that is quite opposite to what we seen in the previous step, we referred to the HDI variable of Turkey. The VIF test provides conclusive evidence of multicolinearity in the concerned variable. Then, it is only after adjustment we concluded that none of the variables has multicollinearity issues, all the variables with a tolerance below than 1 and with a VIF between 1 and 10. Therefore, after the reduction in the number of variables (HDI) for every model, we can start our regressions by excluding the variable HDI from every model.

\subsubsection{Stationarity of Data}

Before starting the analysis, the "Augmented Dickey Fuller (ADF) unit root test" and "Zivot-Andrews (ZA) unit root test" allowing for structural breaks to characterize the time series are used for testing the stationarity of all variables.

In ADF test we evaluate the integration order of the series based on the models,

$$
\text { Model A (Intercept): } \Delta Y_{t}=\phi_{1}+\delta Y_{t-1}+\sum_{i=1}^{m} \alpha_{i} \Delta Y_{t-i}+u_{t}
$$

Model B (Intercept+ Trend): $\Delta Y_{t}=\phi_{1}+\delta Y_{t-1}+\phi_{2} t+\sum_{i=1}^{m} \alpha_{i} \Delta Y_{t-i}+u_{t}$ 
Table 9. Unit root tests

\begin{tabular}{|c|c|c|c|c|c|c|c|c|c|c|}
\hline ADF test & & & & & & & & & & \\
\hline \multirow[b]{3}{*}{ Country } & \multirow[b]{3}{*}{ Variables } & \multicolumn{4}{|c|}{ Level } & \multicolumn{4}{|c|}{ First Difference } & \multirow[b]{3}{*}{ Decision } \\
\hline & & \multicolumn{2}{|l|}{$\mathrm{c}$} & \multicolumn{2}{|l|}{$\mathrm{c}, \mathrm{t}$} & \multicolumn{2}{|l|}{$\mathrm{c}$} & \multicolumn{2}{|l|}{$\mathrm{c}, \mathrm{t}$} & \\
\hline & & Prob & Lag & Prob & Lag & Prob & Lag & Prob & Lag & \\
\hline \multirow{7}{*}{ Morocco } & FDI & 0.12 & 1 & 0.36 & 1 & 0.00 & 0 & 0.00 & 0 & Stationary at I(1) \\
\hline & VolEX & 0.00 & 5 & 0.34 & 5 & 0.00 & 4 & 0.00 & 4 & Stationary at $\mathrm{I}(0)$ \\
\hline & Volprice & 0.00 & 0 & 0.00 & 0 & 0.00 & 1 & 0.00 & 1 & Stationary at $\mathrm{I}(0)$ \\
\hline & GDP & 0.02 & 3 & 0.52 & 2 & 0.00 & 2 & 0.00 & 4 & Stationary at $\mathrm{I}(0)$ \\
\hline & INFRA & 0.23 & 1 & 0.12 & 3 & 0.11 & 0 & 0.26 & 0 & Stationary at I(2) \\
\hline & OP & 0.82 & 0 & 0.06 & 0 & 0.00 & 0 & 0.00 & 0 & Stationary at I(1) \\
\hline & PR & 0.00 & 1 & 0.00 & 1 & 0.00 & 0 & 0.00 & 0 & Stationary at $\mathrm{I}(0)$ \\
\hline \multirow{7}{*}{ Turkey } & FDI & 0.29 & 0 & 0.44 & 0 & 0.00 & 0 & 0.00 & 0 & Stationary at I(1) \\
\hline & VolEX & 0.14 & 0 & 0.14 & 1 & 0.00 & 0 & 0.00 & 5 & Stationary at I(1) \\
\hline & Volprice & 0.54 & 0 & 0.72 & 0 & 0.00 & 0 & 0.02 & 0 & Stationary at I(1) \\
\hline & GDP & 0.00 & 0 & 0.00 & 0 & 0.00 & 0 & 0.00 & 0 & Stationary at $\mathrm{I}(0)$ \\
\hline & INFRA & 0.09 & 3 & 0.09 & 0 & 0.44 & 0 & 0.86 & 0 & Stationary at I(2) \\
\hline & OP & 0.16 & 0 & 0.00 & 3 & 0.00 & 1 & 0.00 & 1 & Stationary at $\mathrm{I}(0)$ \\
\hline & PR & 0.36 & 0 & 0.69 & 0 & 0.03 & 0 & 0.12 & 0 & Stationary at I(1) \\
\hline
\end{tabular}

Zivot-Andrews

\begin{tabular}{|c|c|c|c|c|c|c|c|}
\hline \multirow[b]{2}{*}{ Country } & \multirow{2}{*}{$\begin{array}{l}\text { Model } \\
\text { Series }\end{array}$} & \multicolumn{2}{|l|}{ Intercept } & \multicolumn{2}{|l|}{ Trend } & \multicolumn{2}{|l|}{ both } \\
\hline & & Statistic & $\begin{array}{l}\text { Time of } \\
\text { break }\end{array}$ & Statistic & $\begin{array}{l}\text { Time } \\
\text { break }\end{array}$ & Statistic & $\begin{array}{l}\text { Time of } \\
\text { break }\end{array}$ \\
\hline \multirow{7}{*}{ Morocco } & FDI & -3.69 & 2001 & -3.67 & 2002 & -4.44 & 2001 \\
\hline & VolEX & $-31.20 * * *$ & 2003 & $-22.16 * * *$ & 2012 & $-20.9 * * *$ & 2012 \\
\hline & Volprice & $-5.35 * * *$ & 2000 & $-4.87 * * *$ & 2004 & $-5.37 * *$ & 2005 \\
\hline & GDP & $-12.82 * * *$ & 2001 & $-5.30 * * *$ & 2008 & $-5.11 * *$ & 2007 \\
\hline & INFRA & $-5.99 * * *$ & 2007 & -3.37 & 2013 & $-10.1 * * *$ & 2007 \\
\hline & $\mathrm{OP}$ & $-4.70 *$ & 2005 & -3.88 & 2013 & -4.46 & 2005 \\
\hline & INSTIT & \multicolumn{6}{|c|}{ NEAR SINGULAR MATRIX } \\
\hline \multirow{7}{*}{ Turkey } & FDI & -4.36 & 2005 & -3.63 & 2008 & $-5.57 * * *$ & 2005 \\
\hline & VolEX & $-9.20 * * *$ & 2002 & $-10.44 * * *$ & 2006 & $-13.1 * * *$ & 2002 \\
\hline & Volprice & -4.42 & 2005 & -2.57 & 2002 & $-6.43 * * *$ & 2005 \\
\hline & GDP & $-5.79 * * *$ & 2003 & $-5.47 * * *$ & 2000 & $-5.68 * * *$ & 2002 \\
\hline & INFRA & $-7.11 * * *$ & 2011 & $-5.39 * * *$ & 2014 & $-5.29 * *$ & 2011 \\
\hline & OP & -4.03 & 2009 & $-5.60 * * *$ & 1997 & $-7.89 * * *$ & 1998 \\
\hline & INSTIT & -2.70 & 2002 & -1.60 & 2002 & -2.68 & 2013 \\
\hline
\end{tabular}

\footnotetext{
: $10 \%$ significance

**: $5 \%$ significance

***: $1 \%$ significance
} 
Taking into account the findings of the ADF tests, the models are specified using either levels or first differences of the explanatory variables excluding infrastructure that turned out to become stationary within two differencing.

Because the period of our study has been characterized by serious global economic crisis and structural changes, to have a better idea on the characteristics of the series, we apply Zivot Andrews (ZA) unit root test allowing single endogenous structural break whether at the level, with trend or "level+trend". For Turkey all the variables are stationary at level excluding institutional quality. The structural break point (in level+ trend) of FDI in Turkey was in 2005, at this time FDI inward flows of Turkey showed a tremendous increase by reaching $10 \$$ billion after the enactment of the Foreign Direct Investments Law (FDIL) in 2003. For Morocco, break points for both GDP and Infrastructure were in 2007, coinciding with the Financial Economic crisis.

After using ZA method, it appears that infrastructure becomes stationary at level in both cases. Which mean that these series are integrated of order zero. Therefore, this method could exclude the existence of variables integrated of order I (2). Thus, we can proceed to the ARDL model.

\subsubsection{ARDL Model}

The autoregressive distributed lag "ARDL" model was introduced by Pesaran et al. (2001) is employed to estimate both short and long term effects of price and exchange rate volatility on FDI inflows. ARDL model can perform bound test of cointegration with mixed results in the orders of stationarity of variables.

The bounds tests suggest that the variables of interest are bound together in the long-run when foreign direct investment is the dependent variable.

$$
\begin{aligned}
& \Delta \text { FDI }_{\mathrm{it}}=\alpha_{0}+\alpha_{1} \text { FDI }_{\mathrm{t}-1}+\alpha_{2} \pi_{\mathrm{it}-1}+\alpha_{3} \operatorname{VolEX}_{\mathrm{it}-1}+\alpha_{4} \operatorname{INSTIT}_{\mathrm{it}-1}+\alpha_{5} \mathrm{GDP}_{\mathrm{it}-1}+\alpha_{6} \mathrm{OP}_{\mathrm{it}-1}+\alpha_{7} \mathrm{INFRA}_{\mathrm{it}-1}+ \\
& \sum_{\mathrm{i}=0}^{\mathrm{h}} \lambda_{2} \Delta \pi_{\mathrm{it}-\mathrm{a}}+\sum_{\mathrm{b}=0}^{\mathrm{h}} \lambda_{3} \Delta \operatorname{VolEX}_{\mathrm{it}-\mathrm{b}}+\sum_{\mathrm{c}=0}^{\mathrm{h}} \lambda_{4} \Delta \mathrm{INSTIT}_{\mathrm{it}-\mathrm{c}}+\sum_{\mathrm{d}=0}^{\mathrm{h}=0} \lambda_{5} \Delta \mathrm{GDP}_{\mathrm{it}-\mathrm{d}}+\sum_{\mathrm{e}=0}^{\mathrm{h}} \lambda_{6} \Delta \mathrm{OP}_{\mathrm{it}-\mathrm{e}}+ \\
& \sum_{\mathrm{f}=0}^{\mathrm{h}} \lambda_{7} \Delta \text { INFRA }_{\mathrm{it}-\mathrm{f}}+\varepsilon_{\mathrm{it}}
\end{aligned}
$$

Where,

$\Delta$ is the backshift operator;

$\lambda_{j}(j=1, \ldots . .7)$, represent the short-run coefficients of variables at lag orders: a,b,c,d,e, and f;

$\alpha_{j}(j=1, \ldots . .7)$, show the long-run coefficients to test the null hypothesis of no cointegration;

" $\mathrm{h}$ " denotes the lag length that obtained using Akaike Information Criterion (AIC);

$\alpha_{0}$, indicates the intercept term;

$\varepsilon_{i t}$, represents the white noise error term.

3.2.5.1 ARDL Bounds Test

Table 10. Bounds test for cointegration analysis

\begin{tabular}{lllllll}
\hline & & & & & \\
\cline { 3 - 6 } Country & F-Stat & $95 \%$ lower Bound & $95 \%$ Upper Bound & $\begin{array}{l}90 \% \\
\text { Bound }\end{array}$ & Lower & $\begin{array}{l}90 \% \\
\text { Bound }\end{array}$ \\
\hline Morocco & $11.49^{*}$ & 2.79 & 4.14 & 2.33 & 3.51 \\
Turkey & $6.54^{* *}$ & 3.32 & 4.65 & 2.78 & 3.94 \\
\hline
\end{tabular}

* Case 2 Restricted Constant and No Trend

${ }^{* *}$ Case 4 Unrestricted Constant and Restricted Trend

From the ARDL bounds test result; we found that there is cointegration between the variables specified in the models as it reveals the F-statistic value which is greater than the upper and lower boundary of the result at 5\% and $10 \%$ level of significance.

\subsubsection{Diagnostic Test}

Table 11. Diagnostic tests

\begin{tabular}{lll}
\hline Test Statistics & Morocco & Turkey \\
\hline Serial Correlation "LM" & 0.74 & 0.28 \\
Functional Form "Ramsey" & 0.17 & 0.13 \\
Normality of errors & 0.56 & 0.65 \\
Heteroscedasticity "ARCH" & 0.27 & 0.94 \\
\hline
\end{tabular}


The table above shows us the four diagnostic tests for ARDL estimations of each country. For both models the results seem positive. We start by the serial correlation test where the null hypothesis of no autocorrelation between variables is accepted for both models. The Ramsey's RESET test shows that the functional form is well applied for the two models. Regarding to the normality tests, we accept the null hypothesis, for both cases, which assumes that the residuals are normally distributed. The last test is the Autoregressive conditional Heteroskedasticity (ARCH) test where we accept the null hypothesis of homocedasticity for each case.

The additive test for identifying the goodness of fit of the models is stability tests. For this reason, we perform cumulative sum (CUSUM) and cumulative sum of squares (CUSUMQ) tests. As seen below in figure(1), the coefficients of every model are stable over time observation since the plot of CUSUM and CUSUMQ test statistics fall within the boundaries.

In conclusion, the model of each country passes in all diagnostic tests, which makes it feasible for estimating the effects between independent variables and the dependent variable on both the short and long-term.
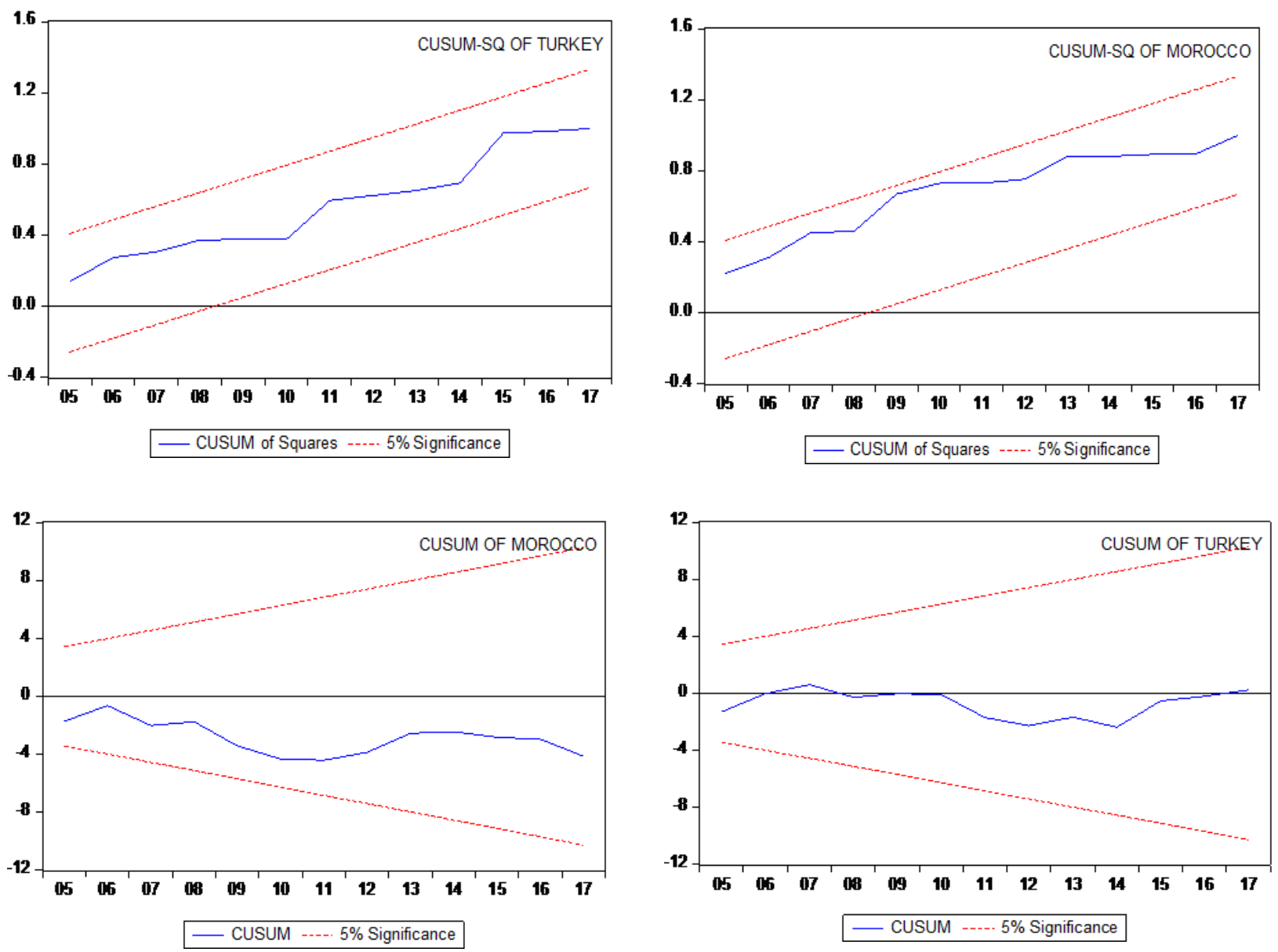

Figure 1. CUSUM/CUSUM-SQ

\section{Result and Discussion}

\subsection{Long-run ARDL}

Table 12. Long-term estimations of FDI inflows

\begin{tabular}{|c|c|c|c|c|c|c|}
\hline \multirow[b]{2}{*}{ Variables } & \multicolumn{3}{|l|}{ Morocco } & \multicolumn{3}{|l|}{ Turkey } \\
\hline & Coefficients & Std.Error & T-Ratio [Prob] & Coefficients & Std.Error & T-Ratio [Prob] \\
\hline VolEX & $(-) 1.86$ & 0.70 & $-2.65 * * *[0.01]$ & 0.70 & 1.02 & $0.69[0.50]$ \\
\hline volprice & 0.07 & 0.03 & $1.93 *[0.07]$ & (-) 0.02 & 0.006 & $-3.17 * * *[0.00]$ \\
\hline GDP & 0.40 & 0.08 & $4.80 * * * \quad[0.00]$ & 0.21 & 0.07 & $2.92 * * *[0.01]$ \\
\hline OP & 0.03 & 0.01 & $2.82 * * * \quad[0.01]$ & (-) 0.05 & 0.05 & $-0.88[0.39]$ \\
\hline INSTIT & 0.03 & 0.01 & $2.65 * * * \quad[0.01]$ & (-) 0.005 & 0.002 & $-2.67 * * *[0.01]$ \\
\hline INFRA & (-) 0.17 & 0.04 & $-4.05 * * *[0.00]$ & 0.22 & 0.08 & $2.72 * * *[0.01]$ \\
\hline & (-) 0.16 & 0.05 & $-2.78 * * *[0.01]$ & & & \\
\hline Trend & & & & 0.0012 & 0.0004 & $2.54 * *[0.02]$ \\
\hline
\end{tabular}

*: $10 \%$ significance

**: $5 \%$ significance

***: $1 \%$ significance 


\subsubsection{Moroccan Case}

According to the result of long-term estimates of FDI inflows, it seems that the exchange rate volatility rejects the null hypothesis through the p-value at $1 \%$, which means it is statistically significant next to GDP growth, trade openness, infrastructure and political rights. These variables also show the expected sign that each statistical variable has, excluding the information infrastructure that does not have the expected sign but remains significant.

It has been said that the depreciation of the local currency in the host country is likely to attract FDI inflows for two main reasons. First, the depreciation of the currency reduces the costs of production in the host country, making it more attractive for FDI in terms of seeking efficiency. Second, the depreciation of the currency decreases the value of assets in the host country in terms of other currencies, including the currency of the original country. As a result, host countries become more attractive by the depreciation of their currency. In addition, since the FDI in Morocco tends to be vertical (intended for export) rather than horizontal (aimed at the market of host countries) in nature, a weaker domestic currency "dirham" might be expected to increase vertical FDI as firms take advantage of relatively low prices in host markets to increase home-country profits on goods that will be exported entirely to a third market (see Froot, Kenneth A, and Jeremy C Stein, 1991). These have been proved by our result, by the fact that an increase of $1 \mathrm{pp}$ (Percent point) of the volatility of the real exchange rate leads to a decrease of the level of inward FDI flows by $1.86 \mathrm{pp}$.

Regarding the volatility of the inflation, it is clear from the results achieved that it shows the expected result despite the fact that the null P-value is "not significant" at the 0.05 level. This result goes in line with findings of Lucas and Prescott (1971), Abel (1983) and Ramey and Ramey (1995) who explained that this positive relationship between investment and inflation uncertainty is due to the fact that the existence of high uncertainty raises the marginal profitability of capital and hence increase investment. Likewise, to the fact of the precautionary savings motive, higher volatility should lead to a higher savings rate, and hence a higher investment rate. Therefore, FDI inflows in Morocco are less elastic to domestic price fluctuation than to exchange rate volatility.

Looking to the number of fixed phone lines, which has been used as proxy for infrastructure by different authors such as, Sekkat and Veganzones (2004), Asiedu (2006), Nayyra Zeb and al. (2014) and Tidiane Kinda (2008), Rehman and al. (2011), the result shows a negative and significant effect on FDI. This result can be explained by the poor quality of the fixed telephone infrastructure in Morocco. This result is similar to that obtained by Colin Kirkpatrick and al. (2006), although the effect is not considered significant, in contrast to the studies of Campos and Kinoshita (2003), and Settak and Veganzones (2004), Asiedu (2006), Mumtaz Hussain Shah (2014), Nayyra Zeb, Fu Qiang and Muhammad Shabbir (2014), and Ngwen Ngangue (2016).

Turning to trade openness, it has a positive and significant effect on the level of FDI in Morocco. Our findings are consistent with those of Edwards (1990), Hausmann and Fernandez-Arias (2000), Chakrabarti (2001), Amal et al. (2010). The common thread in all these studies is that the export-oriented policies of $\mathrm{MNE}^{4}$ may prefer to locate in more open economies, in order to minimize the transaction costs associated with exporting.

Concerning the potential market size that is proxied by GDP growth rate appears to be an important determinant of FDI flows. Following Pearce et al., 1992, Lunn (1980) found that it is better to employ growth rate of GDP than the level of GNP to avoid spurious correlation for controlling potential market size. Table above reports a positive and significant impact on FDI to Morocco. Hence, market-seeking investment is attracted by the market potential size of the host country. This shifted some power over government.

Concluding with the institutional quality, which was used to assess the condition of political rights of Morocco, a positive and significant value of this variable pushed us to think about the process of reform that Morocco has pursued since the last constitution adopted by popular referendum on 1 July 2011. This helps Morocco to become more transparent, reactive and responsible than before even with a rate a little slow to encourage more FDI into Morocco.

\subsubsection{Turkish Case}

For the case of Turkey our findings show positive and insignificant impact of the exchange rate volatility. As for the positive effect of Exchange rate volatility although statistically insignificant, well known references in this subject are Walter Oi (1961), Arrow (1968), Lucas and Prescott (1971), Abel (1983), Bernanke (1983), Cushman (1988), Caballero (1991), Abel and Eberly (1994), Dixit and Pindyck (1994), Cheong et Al.(2005), Hwang and Lee (2005), and Kim (2017) suggest that heightened volatility of exchange rate gives rise to higher investment.

Following from Cushman's study (1988), the findings of this study show that the higher exchange rate volatility was found to be associated with higher direct investment inflows in the United States. Another study of Goldberg and Kolstad

4 MNE: is the abbreviation of Multinational Entreprises and sometimes also called multinational Corporation, are enterprises which conducts business operations in various countries with its subsidiaries and affiliates. 
(1995) analyzed the effect of short-run exchange rate variability on US bilateral FDI flows, they found that exchange rate uncertainty had a positive and statistically significant effect on FDI shares by the fact that real exchange rate volatility increased the share of total US investment capacity located abroad and in parallel increased the share of the foreign investment located in the United States. Likewise, exchange rate depreciations led to a reduction in investment flow shares to foreign.

Turning to price volatility, it is possible to see that it has the expected sign on the dependent variable. Generally, inflation raises the user cost of capital, and consequently affects negatively the profitability of FDI. Based on these two main variables of uncertainty (exchange rate and inflation), it can be argued that FDI is more elastic to domestic price fluctuations than to exchange rate volatility. Therefore, a $1 \mathrm{pp}$ rise in the inflation volatility leads to a decrease of $0.02 \mathrm{pp}$.

The infrastructure variable turned out statistically significant. In addition, it is has had a positive impact to attract FDI to Turkey. This obtained coefficient represents that one percent point increase in infrastructure increases FDI by almost 0.22 $\mathrm{pp}$, which proved what we noticed during the last two decades, how Turkey's telecommunication sector have seen significant changes. In fact, Turkey's telecommunication history is over a century old, 1847 was characterized by the installation of the first telegraph line and the first telephone circuit in 1881. Huge investments were made between the 1980s and 1990s to modernize infrastructure sector. In this regard, Turkey is increasingly interested in such a sector and has launched the necessary studies to be able to express itself in the context of technologies in the future. For this reason, we can assume that the time trend may have a significant effect in the model of Turkey.

The unexpected result was that of trade openness. It does not trace any significant effect of trade openness on FDI. We can explain this insignificance by the fact that Turkish economy has a long-run problem of trade deficits, although after implementation of different structural reforms process. Macroeconomic adjustment continued more slowly during the first half of 1990s and after the structural economic crisis of 1994 following by two crises, occurring in 1997 and 1999 respectively, which were considered as external shocks. Beside, the flexibility of exchange rate and the fact that there is little input of "hot money" helped dampen more and more the impact of these external shocks. Until now, it seems that Turkish economy could not find any permanent remedy to resolve the problem of its trade deficits which is an important source of external vulnerability for the economy. Hence, Turkey should work more about FDI led policy to enhance its trade openness and exports competitiveness.

The potential market size is statistically significant and appears to be one of the key determinants of FDI inflows in Turkey, particularly market-oriented projects of foreign direct investment.

The last variable used for explaining our regression, is about institutional quality. The negative coefficient is surprising, because this variable tends to be positive and highly significant. In line with our result, we found Diamond (2002), Rudra (2005) and Feng Sun (2014) show democracies in developing countries generally do not bring about improvements in basic rights. This result is consistent with the report of Freedom House, Amnesty International and Human Rights Watch. This report is putting more emphasis on the inefficiency of democracy in Turkey. Based on the historical data issue from "Freedom House", Turkey's status declined from partly-free to not-free from 1990 up to now. Thus, political rights in Turkey have degraded so severely during the observation period that is why the result shows a negative sign coefficient toward FDI inflows. Hence, it seems that Turkey failed to consolidate the promotion of the rule of law and respecting political right. 


\subsection{Short-run ARDL}

Table 13. Short-term estimations of FDI inflows based on AIC

\begin{tabular}{|c|c|c|c|c|c|c|}
\hline \multirow[b]{2}{*}{ Variables } & \multicolumn{3}{|l|}{ Morocco } & \multicolumn{3}{|l|}{ Turkey } \\
\hline & Coefficients & Std.Error & T-Ratio [Prob] & Coefficients & Std.Error & T-Ratio [Prob] \\
\hline$\Delta F D I_{t-1}$ & (-) 1.27 & 0.18 & $-6.99^{* *}[0.00]$ & (-) 0.66 & 0.13 & $-4.76^{* *}[0.00]$ \\
\hline$\Delta F D I_{t-2}$ & (-) 0.15 & 0.09 & $-1.54[0.14]$ & - & _- & _- \\
\hline$\Delta G D P_{t-1}$ & 0.52 & 0.09 & $5.49^{* *}[0.00]$ & 0.14 & 0.03 & $4.18^{* *}[0.00]$ \\
\hline$\Delta I N S T I T_{t-1}$ & 0.04 & 0.01 & $2.69^{* *}[0.01]$ & - & - & - \\
\hline$\Delta O P_{t-1}$ & - & - & - & $(-) 0.03$ & 0.03 & $-0.89[0.38]$ \\
\hline$\Delta$ Volprice $_{t-1}$ & 0.09 & 0.04 & $2.22^{*}[0.04]$ & - & - & - \\
\hline$\Delta \operatorname{Vol}_{t-1}$ & - & - & - & 0.47 & 0.66 & $0.71[0.48]$ \\
\hline$\Delta \operatorname{VolEX}_{t}$ & (-) 2.38 & 0.97 & $-2.43^{*}[0.03]$ & (-) 0.68 & 0.55 & $-1.22[0.24]$ \\
\hline$\Delta$ Volprice $_{t}$ & (-) 0.02 & 0.03 & $-0.48[0.63]$ & (-) 0.01 & 0.004 & $-2.95^{* *}[0.01]$ \\
\hline$\Delta G D P_{t}$ & 0.24 & 0.04 & $4.80^{* *}[0.00]$ & 0.05 & 0.02 & $2.27^{*}[0.04]$ \\
\hline$\Delta O P_{t}$ & 0.04 & 0.01 & $2.58^{* *}[0.02]$ & (-) 0.0004 & 0.025 & $-0.01[0.98]$ \\
\hline$\Delta I N S T I T_{t}$ & 0.003 & 0.009 & $0.36[0.72]$ & (-) 0.003 & 0.001 & $-2.38^{*}[0.03]$ \\
\hline$\Delta I N F R A_{t}$ & (-) 0.22 & 0.05 & $-4.09^{* *}[0.00]$ & 0.15 & 0.04 & $3.16^{* *}[0.00]$ \\
\hline DUM & 0.04 & 0.005 & $7.66^{* *}[0.00]$ & 0.006 & 0.0025 & $2.54^{*}[0.02]$ \\
\hline $\mathrm{C}$ & $(-) 0.21$ & 0.07 & $-2.87^{* *}[0.01]$ & (-) 0.02 & 0.02 & $-0.65[0.52]$ \\
\hline Trend & - & - & - & 0.0008 & 0.0003 & $2.65^{* *}[0.01]$ \\
\hline$R^{2}$ & 0.94 & & & 0.90 & & \\
\hline Adjusted $R^{2}$ & 0.89 & & & 0.83 & & \\
\hline S.E of reg & 0.004 & & & 0.004 & & \\
\hline F-stat & $18.58(0.00)$ & & & $10.92(0.00)$ & & \\
\hline
\end{tabular}

$\Delta:$ operator of teh first differences

*: $5 \%$ significance

**: $1 \%$ significance

Table presents outcomes of short run estimates. In our regressions, the Coefficient of FDI (-1) is ECM, it is negative and statistically significant for both models. We can interpret it as $1.27 \mathrm{pp}$ (for Morocco) and $0.66 \mathrm{pp}$ (for the case of Turkey) short run deviation from the long run equilibrium. The p-value of the coefficient should have statistical significance of $1 \%$ level. Then, it is possible to confirm that these models in the short-run are feasible and stable among the variables.

For the case of Morocco, real effective exchange rate volatility exercise negative impact at $5 \%$ level. It suggests that a $1 \mathrm{pp}$ increase in the volatility of REER causes 2.38 pp decreases in inward FDI flows. In short run GDP and trade openness variables have positive and significant impact as it is the case in long run estimates. Moreover, the infrastructure information possess a negative sign, it confirms that either in the long or in the short run, it has a negative effect on Moroccan FDI inflows. The other variables such as volatility of price and institutional quality do not reject the null hypothesis in the short term.

In relation to the sign of coefficients, it seems that all the variables have the expected impact on inward FDI flows of Morocco excluding infrastructure. This variable has a negative influence on the attractiveness for receiving inward FDI flows to Morocco. However, the inflation volatility and political rights are not statistically significant in the first lag, but they become in the second difference although of the unexpected sign of price uncertainty. This can be explain by the fact that foreign investors tend to make their own decisions to invest by taking into account both the effect of price volatility and the effect of democracy within a past value of two years.

Turning to Turkish case, REER volatility is insignificant, which means that foreign investors are not influenced by the variation of exchange rate. All the other variables are statistically significant and having the expected sign. Despite that the trade openness has a negative sign and statistically insignificant. As regards the short run effect of the institution variable on the dependent variable, it has a significant impact on FDI inflows of Turkey but the sign remains unexpected. 
Thus, the direction of the impact of the explanatory variables on the inward FDI Flows, is the same as found in the long run results discussed above.

Dummy variables are added in our models for shedding more light on economic reforms that have been undergirded by major political changes such as, financial crisis, changes in exchange rate regime, changes in monetary and fiscal policies of each country. Taking the case of Morocco, dummy variable indicates simply the advent of the euro in 2001, the European currencies in the basket are replaced by the new single currency. The significant and positive value of this impact on FDI may be explained by the weight of European countries influx in Morocco's FDI that represent the biggest part of the global amount. Hence, the entry of euro into the currencies basket of Moroccan's dirham has stepped up efforts to attract investment to the country.

For Turkey, several crisis and reform periods are included in the regression such as, 1994 that was characterized by Turkey's currency crisis due to the sharp currency depreciation by almost 70\% against dollar; 1999-2000: Changing in the exchange rate regime from the managed floating system of 1999 to crawling peg system in 2000 (Tablita); Adopting of free-float regime in the aftermath of the February 2001 crisis; 2006 stands for turbulence in the asset markets in MayJune; without forgetting to consider the financial crisis of 2007-2008 and the last period between 2014-2017 that is considered the most noteworthy period concerning the continued fall of the Turkish lira against the US dollar. Generally, the consequences of a currency crisis are considered as a sharp depreciation and can affect foreign companies in different ways (see Soliman, 2005).

As a result, the coefficient for economic and financial crisis under the floating exchange rate regime is considered positive and statistically significant. This result is consistent with the findings of Athukorala (2003) who identified how a currency collapse can exert positive effects on FDI. Hence, whenever there is an occurrence of a financial or economic crisis period due to several economic characteristics. Thus, the extent of structural reforms can therefore generate real benefits to foreign investors by affecting their decision to invest by creating the kind of environment that encourages them to settle in the country, which helps Turkey to overcome the problems faced during the observation period.

\section{Conclusion}

The purpose of this paper was to assess empirically the impact of domestic price and real exchange rate volatility in foreign direct investment inflows. The sample used is based on two MENA countries, Morocco and Turkey for the period 1990- 2017. Countries that have continued to attract considerable FDI inflows while both dealing with their uncertainty fluctuation. We used GARCH-M technique for generating volatility and ARDL model to highlight the short-term and long-term dynamics for FDI inflows. These studies depict the favorable effect of both price and exchange rate volatility on FDI inflows in Morocco and the negative effect of price volatility on FDI inflows of Turkey. Moreover, it is shown that exchange rate volatility in Turkey seems not to be relevant. In short, concerning the potential market size, trade Openness and democracy appear to be important factors for attracting foreign capital in Morocco. Regarding Turkey, both the potential market size and infrastructure were meant to attract more investment to the country. These results are all in line with the literature review on developing countries. This study also explores numerous dimensions such as the role of democracy and good governance in encouraging foreign investors to invest. In conclusion further analysis is needed to better understand the impact of the exchange rate volatility on FDI flows at the industrial level in both countries. It would also be interesting to explore in greater details the effect of the major world currencies (dollar and euro) volatility on foreign investment in each sector of activity to each country apart.

\section{References}

Abbott, A., Cushman, D. O., \& De Vita, G. (2012). Exchange Rate Regimes and Foreign Direct Investment Flows to Developing Countries. Review of International Economics, 20(1), 95-107. https://doi.org/10.1111/j.1467-9396.2011.01010.x

Abel, A. B. (1983). Optimal Investment Under Uncertainty. The American Economic Review, 73(1), 228-233. Retrieved from http://repository.upenn.edu/fnce_papers/220

Aizenman, J. (1992). Exchange Rate Flexibility, Volatility, and the Patterns of Domestic and Foreign Direct Investment. Working Paper no. 3953, National Bureau of Economic Research. https://doi.org/10.5089/9781451843798.001

Akin, M. Ş. (2009). How Is the Market Size Relevant as a Determinant of FDI in Developing Countries? A Research on Population and the Cohort Size. Paper presented at International Symposium on Sustainable Development, June 2009, Sarajevo.

Alba, J. D. A., Park, D., \& Wang, P. (2010). Corporate governance and foreign direct investment. Asian Development Bank Economics, Working Paper No.202. https://dx.doi.org/10.2139/ssrn.1633702

Amal, M., Tomio, B. T., \& Raboch, H. (2010). Determinants of foreign direct investment in Latin America. Global. Competitiveness Governability 4(3), 116-133. 
Aqeel, A., \& Nishat, M. (2004). The determinants of foreign direct investment in Pakistan. The Pakistan Development Review, 43(4), 651-664. https://doi.org/10.30541/v43i4IIpp.651-664

Asiedu, E. (2006). Foreign direct investment in Africa: The role of natural resources, market size, government policy, institutions and political instability. The World Economy, 29(1), 63-77. https://doi.org/10.1111/j.1467-9701.2006.00758.x

Athukorala, P. C. (2003). Foreign direct investment in crisis and recovery: lessons from the 1997-1998 Asian crisis. https://doi.org/10.1111/1467-8446.t01-1-00051

Azman-Saini, W. N. W., Baharumshah, A. Z., \& Law, S. H. (2010). Foreign direct investment, economic freedom and economic growth: International evidence. Economic Modelling, 27(5), 1079-1089. https://doi.org/10.1016/j.econmod.2010.04.001

Azmat, G., \& Basu, S. (2004). The effects of foreign direct investment on human development. Global Economy Journal, 4(2), 1-20. https://doi.org/10.2202/1524-5861.1049

Baccini, L., \& Urpelainen, J. (2014). International institutions and domestic politics: can preferential trading agreements help leaders promote economic reform? The Journal of Politics, 76(01), 195-214. https://doi.org/10.1017/S0022381613001278

Barrell, R., Gottschalk, S. D., \& Hall, S. G. (2004). Foreign Direct Investment and Exchange Rate Uncertainty in Imperfectly Competitive Industries. Tanaka Business School Discussion Paper, TBS/DP04/7.

Baum, C. F., Pundit, M., \& Ramayandi, A. (2017). Capital flows and financial stability in emerging economies. Asian Development Bank, 522. Retrieved from https://www.adb.org/sites/default/files/publication/372256/ewp-522.pdf https://doi.org/10.22617/WPS179090-2

Bénassy-Quéré, A., Fontagné, L., \& LahrÈche-Révil, A. (2001). Exchange-Rate Strategies in the Competition for Attracting Foreign Direct Investment. Journal of the Japanese and International Economies, 15(2), 178-198. https://doi.org/10.1006/jjie.2001.0472

Bernanke, B. (1983). Irreversibility, Uncertainty and Cyclical Investment. Q. J. Econ, 98, 85-106. https://doi.org/10.2307/1885568

Bibi, S. (2014). Impact of Trade Openness, FDI, Exchange rate and inflation on economic growth: A case study of Pakistan. International Journal of Accounting and Financial Reporting, 4(2), 236-257. https://doi.org/10.5296/ijafr.v4i2.6482

Bird, G., \& Rajan, R. S. (2002). Does FDI guarantee the stability of international capital flows? Evidence from Malaysia. Development Policy Review, 20(2), 191-202. https://doi.org/10.1111/1467-7679.00165

Borensztein, E., Gregorio, Jde., \& Lee, J. W. (1997). How does foreign direct investment affect economic growth. Journal of International Economics, 45, 115-135. https://doi.org/10.1016/S0022-1996(97)00033-0

Bruce, B. M., \& Alastair, S. (2009). A Political Economy of Aid. International Organization, 63(2): 309-340. https://doi.org/10.1017/S0020818309090109

Büthe, T., \& Helen, V. M. (2008). The Politics of Foreign Direct Investment into Developing Countries: Increasing FDI through International Trade Agreements?" American Journal of Political Science, 52(4), 741-62. https://doi.org/10.1111/j.1540-5907.2008.00340

Chakrabarti, A. (2001). The Determinant of Foreign Direct Investment: Sensitivity Analyses of Cross-Country Regressions. Kyklos, 54, 114-189. https://doi.org/10.1111/1467-6435.00142

Cushman, D. (1985) .Real Exchange Rate Risk Expectations, and Exchange Rate Risk during the Floating Period. Rev. Econ. Stat. 67, 302-307.

Dal Bianco, S., Amini, C., \& Signorelli, M. (2017). The Impact of the Global Financial Crisis and the Role of External and Internal Factors in Emerging Economies”. Emerging Markets Finance and Trade, 53, 229-249 https://doi.org/10.1080/1540496X.2016.1216840

Dal Bianco, S., \& Nguyen, C. (2017). FDI Inflows, Price and Exchange Rate Volatility: New Empirical Evidence from Latin America. International Journal of Financial Studies, 5(1), 1-17. http://dx.doi.org/10.3390/ijfs5010006

Dixit, A., \& Pindyck, R. (1994). Investment under uncertainty. Princeton U.press, Chapter 1.

Dropsy, V., \& Grand, N. (2005). Exchange rate and Inflation targeting in Morocco and Tunisia. Macroeconomics 0507018, University Library of Munich, Germany. 
Dür, A., Leonardo, B., \& Manfred, E. (2014). The design of international trade agreements: introducing a new dataset. Review of International Organizations, 9(3), 353-375. https://doi.org/10.1007/s11558-013-9179-8

Ellahi, N. (2011). Exchange rate volatility and foreign direct investment (FDI) behavior in Pakistan: A time series analysis with auto regressive distributed lag (ARDL) application". African Journal of Business Management, 5(29), 1165611661.

Feng, S. (2014). The dual political effects of foreign direct investment in developing countries. The Journal of Developing Areas, 48(1), 107-125. https://doi.org/10.1353/jda.2014.0020

Filipe de, S. M. J., Laureano, L., \& Barradas, R. (2015). Impact of Real Exchange Rate Volatility on Foreign Direct Investment Inflows In Brazil. Conferral of MSc. In Finance. Instituto Universitario de Lisboa.

Froot, K. A., \& Jeremy, C. S. (1991). Exchange Rates and Foreign Direct Investment: An Imperfect Capital Markets Approach. Quarterly Journal of Economics, 106, 1191-1217. https://doi.org/10.2307/2937961

Goldberg, L., \& Kolstad, C. (1995). Foreign direct investment, Exchange rate variability and Demand uncertainty. Interational Economic Review, 36(4), 855-73. https://doi.org/10.2307/2527262

Hartman, R. (1972). The Effects of Price and Cost Uncertainty on Investment. Journal of Economic Theory, 5, $258-266$. https://doi.org/10.1016/0022-0531(72)90105-6

Hausmann, R., \& Fernández-Arias, E. (2000). Foreign direct investment: Good cholesterol? Working Paper, No. 417, Washington, DC: Inter-American Development Bank, Research Department.

Hock, L. K., Su, Y. T., \& Wai, K. T. (2016). Global Financial Crises: Origin and Management. International Journal of Economics and Financial Issues, 6(S3), 92-98.

Itagaki, T. (1981). The Theory of the Multinational Firm Under Exchange Rate Uncertainty. Canadian Journal of Economics, 14, 276-97. https://doi.org/10.2307/134798

Kirkpatrick, M. P., Ackerman, A. S., Stevens, D. E., \& Mansour, N. N. (2006). On the application of the dynamic Smagorinsky model to large-eddy simulations of the cloud-topped atmospheric boundary layer. J. Atmos. Sci., 64, 526-546. https://doi.org/10.1175/JAS3651.1

Lemi, A., \& Asefa, S. (2001). Foreign direct investment and uncertainty: Implications for Ethiopia. International Conference on African Development Archives. 20. Retrieved from https://scholarworks.wmich.edu/africancenter_icad_archive/20

Libsey, R. E. (2001). Foreign direct investment and the operations of multinational firms: Concepts, History, and data. NBER working Paper No.8665. https://doi.org/10.3386/w8665

López, N., G., \& Zamudio, F. J. J. (2018). The effect of uncertainty on Foreign Direct Investment: the case of Mexico. Working papers n2018-03, Estudios Economicos, 33(1), 117-149. https://estudioseconomicos.colmex.mx/archivo/EstudiosEconomicos2018/117-149Gaby.pdf.

Mahmood, I, Ehsanullah, M., \& Ahmed, H. (2011). Exchange rate volatility \& macroeconomic variables in Pakistan. Business Management Dynamics, 1(2), 11-22.

Milner, M., \& Keiko, K. (2005). Why the Move to Free Trade? Democracy and Trade Policy in the Developing Countries. International Organization, 59(1), 107-43. https://doi.org/10.1017/S002081830505006X

Mumtaz, H. S. (2016). Trade liberalization and FDI inflows in emerging economies. Business \& Economic Review, 8(1), 35-52. https://doi.org/10.22547/BER/8.1.3

Nayyra, Z., Qiang, F., \& Rauf, S. (2014). Role of foreign direct investment in economic growth of Pakistan. International Journal of Economics and Finance, 6(1). https://doi.org/10.5539/ijef.v6n1p32

OECD. (2002). Foreign direct investment for development: Maximising benefits, Minimising costs. Overview. Paris: OECD Publications. https://doi.org/10.1787/9789264199286-en

Pesaran, M. H., \& Shin, Y. (1999). An Autoregressive Distributed Lag Modelling Approach to Cointegration Analysis. Strom, S. (ed.) Econometrics and Economic Theory in the 20th Century, Cambridge, Cambridge University Press.371-413. https://doi.org/10.1017/CCOL521633230.011

Pesaran, M. H., Shin, Y., \& Smith, R. J. (2001). Bounds Testing Approaches to the Analysis of Level Relationships. Journal of Applied Econometrics, 16(1), 289-326. https://doi.org/10.1002/jae.616

Ramey, G., \& Ramey. V. A. (1995). Cross-country evidence on the link between volatility and growth. The American Economic Review, 85(5), 1138-1151. Retrieved from http://www.jstor.org/stable/2950979 
Svrtinov, G., Gorgieva-Trajkovska, O., \& Kostadinovski, A. (2013). The impact of financial instability on FDI dynamics. International Scientific Conference: "Finance and Economic Accounting-the Current Situation, Trends and Prospects. Retrieved from http://eprints.ugd.edu.mk/8576/

Yousaf, S., Shahzadi, I., Kanwal, B., \& Hassan, M. (2013). Impact of Exchange Rate Volatility on FDI in Pakistan. IOSR J.Bus. Manag, 12, 79-86. https://doi.org/10.9790/487X-1217986

Zühal, K., \& Yasemin, Y. A. (2017). Relationship between Institutional Factors and FDI flows in Developing Countries: New Evidence from Dynamic Panel Estimation”. Economies, 5, 17.

\section{Copyrights}

Copyright for this article is retained by the author(s), with first publication rights granted to the journal.

This is an open-access article distributed under the terms and conditions of the Creative Commons Attribution license which permits unrestricted use, distribution, and reproduction in any medium, provided the original work is properly cited. 